Biological and Applied Sciences

Vol.59: e16160235, January-December 2016 http://dx.doi.org/10.1590/1678-4324-2016160235 ISSN 1678-4324 Online Edition

\title{
Phytochemical and Morphological Evidences for Shikonin Production by Plant Cell Cultures of Onosma sericeum Willd
}

\author{
Sormeh Gharehmatrossian ${ }^{1}$; Yu Popov¹; Mahlagha Ghorbanli²; Shila Safaeian ${ }^{3}$; Alireza \\ Iranbakhsh ${ }^{4}$. \\ ${ }^{I}$ Yerevan State University, 0025, Yerevan, Armenia Yerevan State University, Armenia. ${ }^{2}$ Islamic Azad University, \\ Gorgan Branch, Gorgan, Iran. ${ }^{3}$ Marin Science Faculty of Islamic. Azad University, Nabsh assef. Valiaser st. \\ Tehran. Iran. ${ }^{4}$ Department of Biology, Science and Research Branch, Islamic Azad University, Tehran, Iran.
}

\begin{abstract}
Shoot regeneration, callus growth, and biosynthesis of shikonin in callus cultures of Onosma sericeum were examined. Plant tissue culture was used as an alternative method for increasing the production of shikonin, a secondary metabolite. The isolated cultures were subjected to abiotic factors such as light, plant growth regulators, and nutritional factors. Identification was carried out by High-Performance Liquid Chromatography (HPLC) after 10th subculture. Nodal explants were incubated in Murashige and Skoog (MS) medium along with different combination of growth hormones. Shoot regeneration from calli were achieved on MS basal medium supplemented with $3 \mathrm{mg} / \mathrm{l}$ 6-benzylaminopurine (BAP) and $0.5 \mathrm{mg} / \mathrm{l}$ Naphthalene acetic acid (NAA) under light cycle. Shikonin was formed in dark culture. Calli grown on MS (ammonium ion-free) medium supplemented with $3 \mathrm{mg} / \mathrm{l}$ BAP and $0.5 \mathrm{mg} / \mathrm{l}$ NAA contained the maximum shikonin level $(15.26 \mu \mathrm{g} / \mathrm{mg} \mathrm{DW})$. Minimum shikonin content $(9.85 \mu \mathrm{g} / \mathrm{mg}$ $D W$ ) was observed in calli cultured on MS (ammonium ion-free) medium supplemented with $3 \mathrm{mg} / \mathrm{B}$ BAP and 0.5 $m g / l$ indole-3-acetic acid (IAA). In establishing cell culture, the ammonium ion, and light cycle inhibited shikonin formation. This is the first report on the establishment of isolated cultures of $O$. sericeum for shikonin production and callus growth.
\end{abstract}

Key words: Growth index; Medicinal plant; Plant regeneration; Secondary metabolite

*Authors for correspondence: silva41526@gmail.com 


\author{
ABBREVIATIONS \\ HPLC High Performance Liquid Chromatography \\ MS Murashige and Skoog (1962) \\ BAP 6-benzylaminopurine \\ NAA Naphthalene acetic acid \\ IAA Indole-3-acetic acid \\ DW Dry weight \\ L/D Light/Dark \\ GI Growth index \\ FW Fresh weight
}

\section{INTRODUCTION}

Onosma sericeum (Boraginaceae) is a perennial herb which grows naturally in Iran (Mozaffarian 2007). Onosma sericeum Willd. accumulates red pigment (shikonin derivatives) in its root, which is used as a natural dye in food, cosmetics, textiles and exhibit various medicinal and pharmaceutical properties (Papageorgiou et al. 1999; Babula et al. 2009). The naphthoqinone pigments extracted from Arnebia species show antimicrobial, inflammatory, anti-viral, anti-tumor, cardiotonic and contraceptive properties (Shen et al. 2002; Chen et al. 2003; Singh et al. 2003). These derivatives also, exhibit insulin-like activities by inhibiting phosphatase and tensin homologue deleted on Chromosome 10 (PTEN) and protein tyrosine phosphatases (Nigorikawa et al. 2006). Studies have also revealed specific in vivo and in vitro antitumor effects of acetylshikonin (Xiong et al. 2009). In cell suspension cultures of Lithospermum erythrorhizon, shikonin derivative production is generally inhibited by the addition of $\mathrm{NH}_{4}{ }^{+}$(Fujita et al. 1981). However, the shoots cultured on solid and in liquid MS medium containing high concentrations of $\mathrm{NH}_{4}{ }^{+}$are reported to produce shikonin derivatives (Touno et al. 1998). In fact, the regulatory mechanisms involved are not clear, though the metabolic pathway of the shikonin formation has been wellcharacterized (Yazaki et al. 1999). Among different factors, light appears to be one of the most important consideration regulating the formation of shikonin and its derivatives. In fact, as light completely inhibits these metabolites, their formation is synthesized in dark-cultured cells (Gaisser and Heide 1996; Yazaki et al. 1999). In recent years, various methods and bio-resources are being explored for the production of naphthoquionones through cell culture technology.
It provides a viable alternative over whole plant cultivation for the production of secondary metabolites. Advantages of cell suspension cultures for production of secondary metabolites include supply of product independent of the availability of the plant, climate and geographical location. The possibility of synthesizing novel compounds otherwise not present in nature is an added bonus of cell culture systems (Kutney 1997). Under in vitro conditions, a number of physical and chemical parameters such as temperature and nutrients influence the yield of secondary metabolites (Malik et al. 2011). Cell wall polysaccharides (endogenous or exogenous) especially agar-agar (used as gelling agent in tissue culture medium) and pectin have been reported to influence the yield of secondary metabolites (Papageorgiou et al. 1999). Electron microscopy studies have revealed that naphthoquinone pigments were synthesized in cytosol as lipid vesicles, and later transferred to the outer periphery of plasma membrane for excretion into medium (Tsukada and Tabata 1984). The objective of the study, therefore, was to investigate the effects of light, ammonium ion, phytohormones on the pharmacologically active components of Onosma sericeum Willd, shikonin via isolated culture and the expression of protocol for rapid shoot regeneration from axillary bud explants derived from Onosma sericeum Willd. callus. In addition, we describe cytological observation of red pigment formed in cell cultures by light microscope.

\section{MATERIALS AND METHODS}

The experiment was conducted to investigate shoot regeneration, callus growth, and biosynthesis of shikonin in callus cultures of Onosma sericeum during the period from May 2009 to August 2013.

\section{Source of explants}

During spring season nodal segments each containing the axillary buds were collected from mature plants growing in the Lavasanat near northern Teheran. The plants were identified and authenticated by Professor Mozaffarian, Research Institute of Forests and Rangelands, Teheran, Iran.

\section{Surface sterilization}

Samples were surface sterilized using different treatments. All explants were initially soaked in 
mild liquid detergent, stirred for 10 minutes and then washed in running tap water for 30 minutes. Further, they are dipped in $70 \%$ ethanol for 1 minute and later rinsed in distilled and sterilized water for 2 minutes. Explants were then taken into laminar air flow chamber in Petri dishes and surface sterilized by $2 \%$ sodium hypochlorite solution for 20 minutes and rinsed in distilled and sterilized water for 2 minutes three times. Nodal segments about $0.5-0.8 \mathrm{~cm}$ were prepared aseptically which were then implanted vertically on MS medium.

\section{Media composition}

Explants were placed on four different media. The media employed included (a) MS basal medium supplemented with 6-benzylaminopurine (BAP) (3 $\mathrm{mg} / \mathrm{l})$ and indole-3-acetic acid (IAA) $(0.5 \mathrm{mg} / \mathrm{l})$, (b) MS basal medium supplemented with BAP (3 $\mathrm{mg} / \mathrm{l}$ ) and naphthalene acetic acid (NAA) (0.5 $\mathrm{mg} / \mathrm{l}$ ), (c) MS (ammonium ion-free) medium composed of a combination of BAP $(3 \mathrm{mg} / \mathrm{l})$ and IAA $(0.5 \mathrm{mg} / \mathrm{l})$, and (d) MS (ammonium ion-free) medium composed of a combination of BAP (3 $\mathrm{mg} / \mathrm{l})$ and NAA $(0.5 \mathrm{mg} / \mathrm{l})$. All the media included $3 \%(\mathrm{w} / \mathrm{v})$ sucrose and solidified with $0.8 \%(\mathrm{w} / \mathrm{v})$ agar. The $\mathrm{pH}$ of the media was adjusted to 6 before autoclaving at 15 psi with the temperature set at $121{ }^{\circ} \mathrm{C}$ for $20 \mathrm{~min}$. The cultures were also divided into two groups; the first group was incubated at $25 \pm 1{ }^{\circ} \mathrm{C}$ in the darkness and the second group was maintained in a growth room at $25 \pm 1{ }^{\circ} \mathrm{C}$ under 16/8-h (light/dark) photoperiod. Calli were subcultured on fresh media every 6 weeks to grow.

\section{Growth measurement}

Growth of callus was determined by fresh and dry weight measurement. Callus growth was represented with growth index (GI) which was calculated according the following equation:

\section{Dry matter content $(\%)$}

The fresh calli was dried at $60{ }^{\circ} \mathrm{C}$ for $48 \mathrm{~h}$ and the dry matter content was calculated according the following equation:

Callus dry matter $(\%)=$ Callus dry weight $(\mathrm{DW}) \times$ 100 / Callus fresh weight (FW)

The experiments on calli were conducted with a minimum of five replicates. The data were analyzed statistically using SPSS software version
13. The mean values of different treatments were compared using Duncan's multiple range test $(P<$ $0.05)$.

\section{Extraction of callus}

After $10^{\text {th }}$ passage, the callus was removed then dried, weighed, made chopped into small pieces, and extracted by methanol for $72 \mathrm{~h}$ at room temperature $\left(27 \pm 2.0{ }^{\circ} \mathrm{C}\right)$. The extracts were filtered and then solvents were dried by vacuum rotary evaporator to obtain crude methanolic extract. The dried extract was dissolved in methanol for High Performance Liquid Chromatography (HPLC) identification of shikonin by comparing with standard sample.

\section{HPLC analysis}

Fifty $\mu \mathrm{l}$ of each sample (in $\mathrm{MeOH}$ ) was injected into the HPLC C18 reverse-phase column (TSKgel ODS-80TS; $4.6 \mathrm{~mm}$ ID $\times 150 \mathrm{~mm}$, TOSOH BIOSCIENCE, Japan) and eluted at a flow rate of $1 \mathrm{ml} / \mathrm{min}$. by methanol-water-acetic acid (70:28:2, $\mathrm{v} / \mathrm{v} / \mathrm{v})$. The amounts of shikonin were measured at the wavelength of $245 \mathrm{~nm}$. The elution time of the samples was compared with pure shikonin (SigmaAldrich) and quantified on the basis of the ratio of the peak area of samples to those of the standards. Retention time of shikonin standard was $7.15 \mathrm{~min}$.

\section{Microscopic examination}

For histological investigation, fresh calli were sliced very thin with hand and immediately observed under a light microscope.

\section{Statistical analysis}

Data were subjected to statistical analysis using SPSS software.

\section{RESULTS AND DISCUSSION}

We studied the effects of various concentrations of plant growth substances, light conditions and ammonium ion on growth of callus, pigment formation in callus, and shoot regeneration from nodal explant source. Calli were obtained from nodal explant (containing the axillary bud) which were then grown on different media.

In all cultures, four types of calli could be recognized according to color and texture of callus (Table 1). 
Table 1 Callus texture of O. sericeum in the presence or absence of ammonium ion, various of plant growth regulators, and light conditions

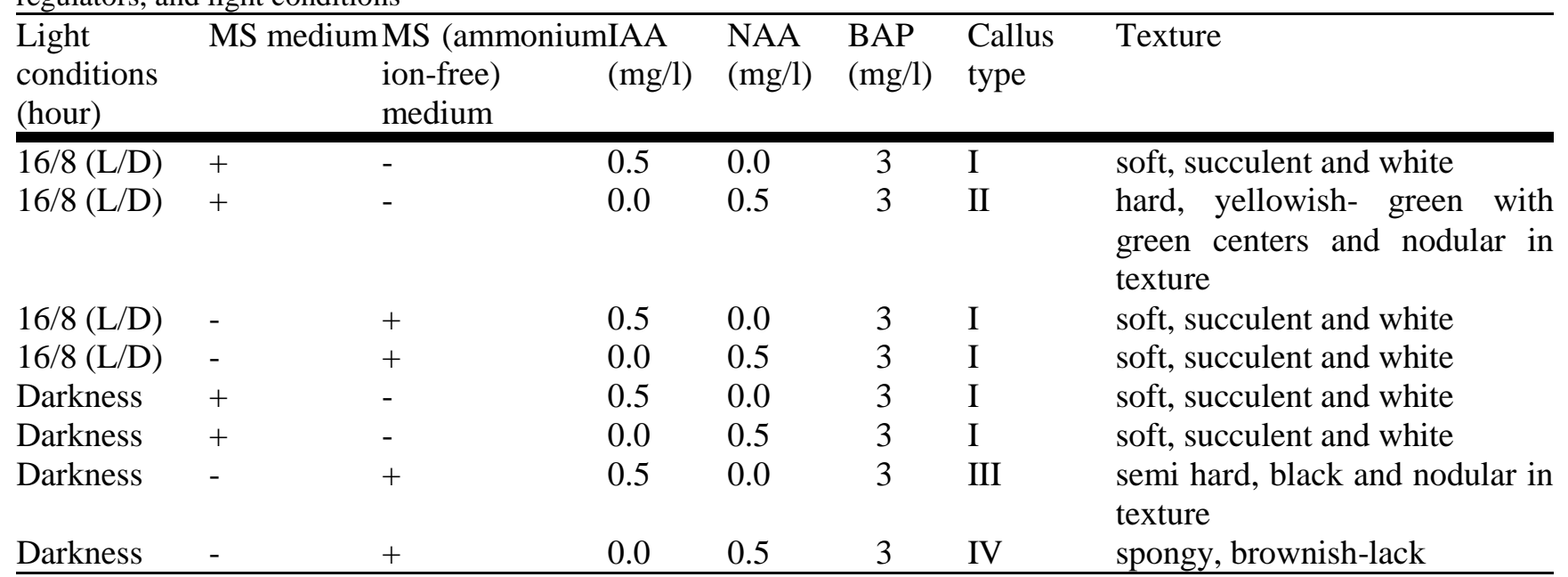

Type I callus was soft, succulent and white (Fig. 1a). These calli were slowly produced on explants. Histological examination showed that cells in Type I calli were irregular and colorless. There was no shikonin in calli grown not only on MS medium supplemented with BAP $(3.0 \mathrm{mg} / \mathrm{l})$ and NAA $(0.5 \mathrm{mg} / \mathrm{l})$ or IAA $(0.5 \mathrm{mg} / \mathrm{l})$ in darkness but also on MS (ammonium ion-free) medium containing BAP $(3.0 \mathrm{mg} / \mathrm{l})$ and NAA $(0.5 \mathrm{mg} / \mathrm{l})$ or IAA $\quad(0.5 \mathrm{mg} / \mathrm{l})$ under $16 / 8-\mathrm{h}$ (light/dark) photoperiod. These results are consistent with previous studies in Lithospermum erythrorhizon by Fujita et al. (1981), Heide et al. (1989) and Yazaki et al. (1999) where shikonin derivative production was inhibited by ammonium ions and light.

Type II calli were hard, yellowish-green with green centers and nodular in texture (Fig. 1b). They had a slow growing habit where the growth of callus from the cut ends of the nodal explants took place within 6-8 weeks. This kind of callus growing on the complete surface of the nodal was observed very frequently. Histological examination showed that cells in Type II calli were in the earliest phase of development into tracheid elements. Nodular explants on MS medium supplemented with BAP $(3.0 \mathrm{mg} / \mathrm{l})$ and NAA $\quad(0.5 \mathrm{mg} / \mathrm{l})$ under $16 / 8$-h (light/dark) photoperiod produced green nodular calli. A similar response was also observed in Justicia gendarussa (Agastian et al. 2006) and Biophytum sensitivum (Linn.) (Shivanna et al. 2009). After second subculture, shoots were found (Fig. 1c). The effective role of BAP in combination with NAA for the induction of multiple shoots has been reported in Basilicum polystachyon (Chakraborty et al. 2006), Musa sapientum L. (Kalimuthu et al. 2007), Rauwolfia serpentina (Baksha et al. 2007), Citrullus colocynthis (Meena and Patni 2007) and Bupleurum distichophyllum (Karuppusamy and Pullaiash 2007), Kaempferia galangal (Shirin et al. 2000). The present study also revealed that the in vitro response, including regeneration, was influenced by MS medium containing BAP (3.0 $\mathrm{mg} / \mathrm{l})$, NAA $(0.5 \mathrm{mg} / \mathrm{l})$ and light condition.

Type III calli were semi hard, black and nodular in texture (Fig. 1d). Histological examination showed that cells in Type III calli were irregular and had different color spots. Nodular callus had potent to produce roots on MS (ammonium ion-free) medium containing BAP $(3.0 \mathrm{mg} / \mathrm{l})$ and IAA $(0.5$ $\mathrm{mg} / \mathrm{l})$ in darkness after $8^{\text {th }}$ subculture. The subculture of the calli on different combinations of hormones was also one of the best effective methods for the differentiation of calli into different organs (Arunkumar and Jayaraj 2011).

Type IV calli were spongy, brownish - black (Fig. 1e). Histological examination showed that cells in Type IV calli were irregular and had different color spots for example colorless, yellow, red, although red spots appeared in cells after 7 months. 


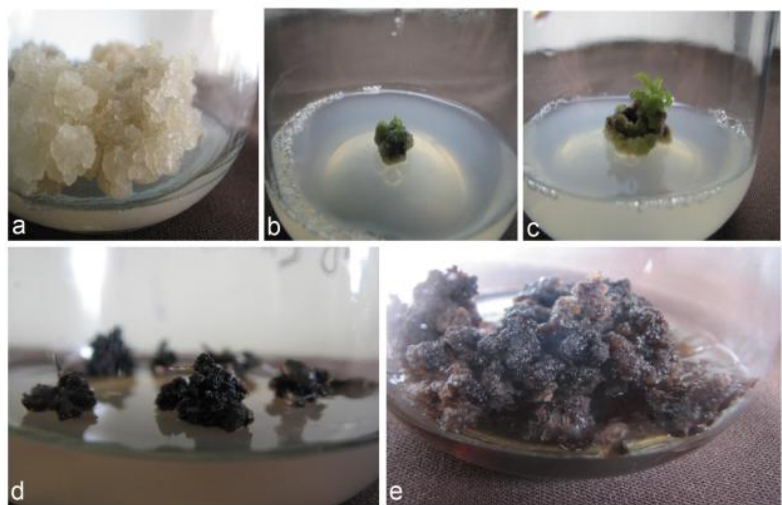

Fig. 1 The morphology of four calli from nodal explant of $O$. sericeum grown on four culture media. (a) White callus produced on $\mathrm{MS}+3 \mathrm{mg} / \mathrm{l} \mathrm{BAP}+0.5 \mathrm{mg} / \mathrm{l} \mathrm{IAA}$ under light cycle. (b) Yellowish-green with green centers callus produced on $\mathrm{MS}+3 \mathrm{mg} / \mathrm{l} \mathrm{BAP}+0.5$ $\mathrm{mg} / \mathrm{l}$ NAA under light cycle. (c) Shoot induction in callus. (d) Black rooted callus produced on MS (ammonium ion-free $)+3 \mathrm{mg} / \mathrm{l} \mathrm{BAP}+0.5 \mathrm{mg} / \mathrm{l} \mathrm{IAA}$ at dark condition. (e) Brownish-black callus produced on $\mathrm{MS}$ (ammonium ion-free) + $3 \mathrm{mg} / \mathrm{l} \mathrm{BAP}+0.5 \mathrm{mg} / \mathrm{l}$ NAA at dark condition.

Deep color spots appeared first on the surface of the callus tissues and then inside the tissue in the late culture stage. Cytological studies revealed that the pigments were formed in numerous groups of parenchyma cells distributed almost randomly throughout the unorganized tissue. In these cells, the water-insoluble pigments (shikonin pigments) were mostly located in a great number of unidentified granules in the cytoplasm, but were also partly excreted from the cells and exposed to the air (Fig. 1e) were managed via vesicle transport. Two hypotheses can be presented for the mechanism of this transport. First, direct transfer of lipids from ER to the plasma membrane and, second, Golgi-mediated exocytosis, as proposed for cuticular wax transport (Mathews et al. 2003). Nevertheless, only negligible amounts of pigments were released from the cells into culture medium. Calli were best if collected fresh. They could be examined fresh for cell concentration, the cytoplasmic movement, cytoplasmic color etc. Cytoplasmic color was very important in our study. It helped not only identify the structures but also determine their composition. Based on prior investigation, different color spots in cells of callus tissue of Onosma sericeum showed chemical compounds convert to each other. In sections of callus tissue of O. sericeum (Types III and VI), five types of color cells were observed under the light microscope: (A) Colorless cells
(Fig. 2a), (B) cells with yellow spot (Fig. 2b), (C) cells with yellow spots that convert to red pigments (Fig. 2c), (D) cells with light red pigment (Fig. 2d), (E) cells with dark red pigment (Fig. 2e), and (F) brown cells (Fig. 2f). Maybe the colorless cells contained colorless oils similar to the oils Yazaki et al. (1986) isolated from shikonin-producing cell suspension cultures of Lithospermum erythrorhizon in M9 medium. These colorless oils included $m$-geranyl- $p$ hydoxybenzoic acid and $m$-geranylhydroquinone. $M$-geranylhydroquinone is an intermediary and when abnormally metabolized, it will form a furan ring on its side chains such as shikonofuran $\mathrm{E}$ and deoxyshikonofuran. However, ammonium ions control $m$-geranylhydroquinone. Lack of ammonium ions in MS medium is one of the special conditions that convert $m$ geranylhydroquinone into deoxyshikonin (Tabata 1996; Papageorgiou et al. 1999). Also, cells with a yellowish spot were observed in the study that was the yellowish liquid of the fresh vesicle fraction turned red when deoxyshikonin was transformed to shikonin pigments via hydroxylation and acylation in the vesicle (Tabata 1996). Also depending on the conditions, $m$ geranylhydroquinone might convert into hydroxyechinofuran B (Fukui et al. 1999). Also depending on the conditions, $m$ geranylhydroquinone might convert into hydroxyechinofuran B (Fukui et al. 1999). Hydroxyechinofuran B is a brown compound (Fukui et al. 1999), and in fact, brown cells were observed in O. sericeum callus tissue sections in the study.
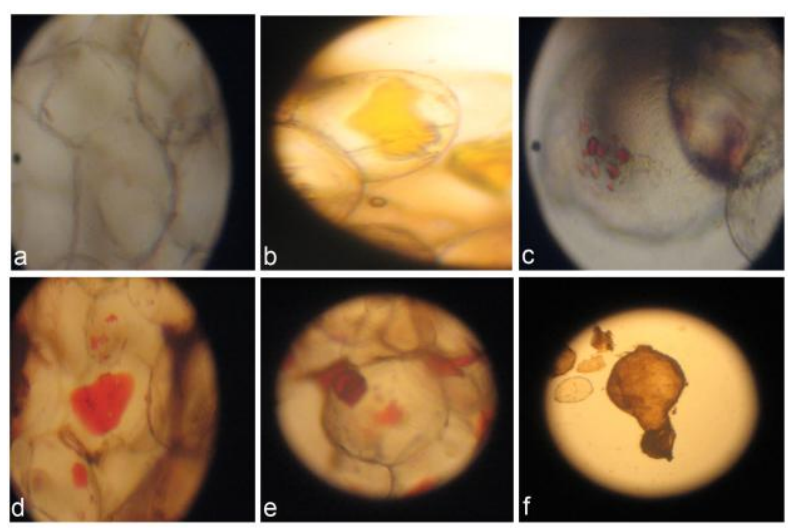

Fig. 2 Sections of callus tissue. (a) Colorless cells. (b) Cell with yellow spot. (c) Cell with yellow spot converts to red pigment. (d) Cells with light red pigment. (e) Cells with dark red pigment. (f) Brown color cell. 
The callus growth rate and the amounts of shikonin produced in the plant callus after $10^{\text {th }}$ subculture are summarized in Table 2.

Table 2 Callus biomass and shikonin production (HPLC assessed) in different types of $O$. sericeum calli grown on different culture media

\begin{tabular}{|c|c|c|c|c|c|}
\hline Culture media & $\begin{array}{l}\text { Fresh weis } \\
(\mathrm{mg})\end{array}$ & $\begin{array}{c}\text { eightDry we } \\
(\mathrm{mg})\end{array}$ & $\begin{array}{c}\text { weightDry matt } \\
\text { content }(\%)\end{array}$ & $\begin{array}{l}\text { rGrowth } \\
\text { index }\end{array}$ & $\begin{array}{l}\text { Shikonin } \\
(\mu \mathrm{g} / \mathrm{g} \mathrm{DW})\end{array}$ \\
\hline$\overline{\mathrm{MS}}+3 \mathrm{mg} / \mathrm{l} \mathrm{BAP}+0.5 \mathrm{mg} / \mathrm{l} \mathrm{IAA} \mathrm{I}$ & $10115.50^{\mathrm{c}}$ & $\begin{array}{ll}{ }^{\mathrm{c}} \quad 236.75^{\mathrm{c}} \\
\end{array}$ & $2.39^{\mathrm{a}}$ & $10.99^{\mathrm{c}}$ & $0.0^{\mathrm{a}}$ \\
\hline $\begin{array}{l}\mathrm{MS}+3 \mathrm{mg} / \mathrm{l} \mathrm{BAP}+0.5 \mathrm{mg} / \mathrm{lI} \\
\mathrm{NAA}\end{array}$ & $9785.75^{c}$ & $236.00^{\mathrm{c}}$ & $2.03^{\mathrm{a}}$ & $10.59^{c}$ & $0.0^{\mathrm{a}}$ \\
\hline $\begin{array}{l}\mathrm{MS} \text { (ammonium ion - free) }+3 \mathrm{III} \\
\mathrm{mg} / \mathrm{BAP}+0.5 \mathrm{mg} / \mathrm{IAA}\end{array}$ & $4078.25^{\mathrm{b}}$ & $183.50^{b}$ & $4.52^{\mathrm{b}}$ & $4.27^{\mathrm{b}}$ & $9.85^{\mathrm{b}}$ \\
\hline $\begin{array}{l}\mathrm{MS}(\text { ammonium ion - free })+3 \mathrm{IV} \\
\mathrm{mg} / \mathrm{BAP}+0.5 \mathrm{mg} / \mathrm{l} \mathrm{NAA}\end{array}$ & $454.00^{\mathrm{a}}$ & $43.00^{\mathrm{a}}$ & $9.51^{\mathrm{c}}$ & $0.975^{\mathrm{a}}$ & $15.26^{\mathrm{c}}$ \\
\hline
\end{tabular}

These measurements taken together provided strong evidence for the production of shikonin in the callus culture. In calli grown on MS medium supplemented with $3 \mathrm{mg} / \mathrm{l} \mathrm{BAP}$ and $0.5 \mathrm{mg} / \mathrm{l} \mathrm{NAA}$ (Type I), the maximum growth index and minimum dry matter content recorded were $10.99 \%$ and $2.32 \%$, respectively and did not contain any shikonin.

The maximum value of shikonin was observed to be $15.26 \mu \mathrm{g} / \mathrm{g}$ DW in calli grown on MS (ammonium ion-free) medium supplemented with $3 \mathrm{mg} / \mathrm{l} \mathrm{BAP}$ and $0.5 \mathrm{mg} / \mathrm{l}$ NAA (Type IV). In contrast, these calli had the lowest growth index $(0.975)$ and the highest dry matter content $(9.51 \%)$. On the other hand, calli grown on MS (ammonium ion-free) medium with combination of $3.0 \mathrm{mg} / \mathrm{l} \mathrm{BAP}$ and $0.5 \mathrm{mg} / \mathrm{l} \mathrm{IAA} \mathrm{(Type} \mathrm{III)}$ produced a lower concentration of shikonin, which was $9.85 \mu \mathrm{g} / \mathrm{g}$ DW. The growth index and dry matter content recorded was found to be $4.27 \%$ and $4.52 \%$, respectively. They were compared with active proliferating calli that had no shikonin contents. This limited growth resulted in higher secondary metabolite content was reported for Solidago chilensis by Schmeda-Hirschmann et al. (2005). It is presumed to be related with environmental and nutritional factors. This finding also confirms the observation of Mathur et al. (2010) for isolated culture of Panax sikkimensis where cultures under 16/8-h (L/D) photoperiodic conditions had less growth and produced higher anthocyanin content and in fact, incubation under continuous light increased the growth index and decreased anthocyanin content.

\section{CONCLUSION}

In conclusion, this paper has described, for the first time, a procedure for initiation and the establishment of callus cultures of Onosma sericeum, which was able to accumulate the level of shikonin. The most important observation of the study is that shikonin production was inversely related to the growth. Variation of the nutrient medium composition and light conditions influenced growth and shikonin accumulation. The best medium for shikonin production was medium (d), i.e., MS (ammonium ion-free) medium composed of a combination of BAP $(3 \mathrm{mg} / \mathrm{l})$ and NAA $(0.5 \mathrm{mg} / \mathrm{l})$ and the most effective stimulator was darkness. Further studies are needed in this area of secondary metabolite production.

\section{REFERENCES}

Agastian P, Williams L, Ignacimuthu S. In vitro propagation of Justicia gendarussa Burm. F.-A medicinal plant. Indian J Biotechnol 2006; 5: 246248.

Arunkumar BS, Jayaraj M. Rapid In vitro Callogensis and Phytochemical Screening of Leaf and Leaf callus of Ionidium suffruticosum, Ging. - A Seasonal Multipotent Medicinal Herb. World J Agricultural Sci. 2011; 7: 55-61.

Babula P, Adam V, Havael L, Kizek R. Noteworthy secondary metabolites naphthoquinones-their occurrence, pharmacological properties and analysis. Curr Pharm Anal. 2009; 5: 47-68.

Baksha R, Jahan MAA, Khatun R, Munshi JL. In vitro rapid clonal propagation of Rauwolifa serpentine (Linn.). Bangladesh J Sci Ind Res. 2007; 42: 37-44

Chakraborty S, Roy SC (2006) Micropropagation of Cyphomandra betacea (Cav.). Sendt. A potential 
horticultural and medicinal plant, by axillary bud multiplication. Phytomorph 56: 29-33

Chen X, Yang L, Oppenheim JJ, Howard OMZ. Cellular pharmacology studies of shikonin derivatives. Phytother Res 2007; 16: 199-209

Fujita Y, Hara Y, Ogino T, Suga C, Morimoto T, Production of shikonin derivatives by cell suspension cultures of Lithospermum erythrorhizon. A new medium for the production of shikonin derivatives. Plant Cell Rep. 1981; 1: 61-63

Fukui H, Feroj Hasan AFM, Kyo M. Formation and secretion of a uniqu quinone by hairy root cultures of Lithospermum erythrorhizon. Phytochem 1999; 51: 511-515

Gaisser S, Heide L. Inhibition and regulation of shikonin biosynthesis in suspension cultures of Lithospermum. Phytochem. 1996; 41: 1065-72

Heide L, Nishioka N, Fukui H, Tabata M. Enzymatic regulation of shikonin biosynthesis in Lithospermum erythrorhizon cell cultures. Phtochem. 1989; 28: 1873-1877

Kalimuthu K, Saravankumar M, Senthilkumar R. In vitro micropropagation of Musa sapientum $\mathrm{L}$. (Cavendish Dwarf). Afr J Biotechnol. 2007; 6: 11061109

Karuppusamy $\mathrm{S}$, Pullaiah $\mathrm{T}$ In vitro shoot multiplication of Bupleurum distichophyllum Wight A native medicinal plant of Southem India. Plant Tissue Cult Biotechnol. 2007; 17: 115-124

Kutney JP. Plant cell culture combined with chemistryroutes to clinically important compounds. Pure App Chem. 1997; 69: 431-436

Malik S, Bhushan S, Sharma M, Ahuja PS. Physicochemical factors influencing the shikonin derivatives production in cell suspension cultures of Arnebia euchroma (Royle) Johnston, a medicinally important plant species. Cell Biol Int. 2011; 35: 153-158

Mathews H, Clendennen Sk, Caldwell CG, Liu XL, Connors K, Matheis N, Schuster DK, Menasco DJ, Wagoner W, Lightner J, Wagner DR. Activation tagging in tomato identifies a transcriptional regulator of anthocyanin biosynthesis, modification, and transport. Plant Cell. 2003; 15: 1689-1703

Mathur A, Mathur AK, Gangwar A, Yadav SH, Verma $\mathrm{P}$, Sangwan RS. Anthocyanin production in a callus line of Panax sikkimensis Ban. In Vitro Cell Dev. Biol - Plant. 2010; 46: 13-21

Meena MC. Patni V. In vitro clon propagation of Citrullus colocynthis (Linn.). Schrad: a threatened medicinal plant. Plant Cell Biotechnol Mol Biol. 2007; 8: 147-152

Mozaffarian V. A dictionary of Iranian plant names. Farhang Moaser Press, Tehran,2007; p 56

Murashige T, Skoog F. A revised medium for rapid growth and bioassays with tobacco tissue culture. Physiol Plant. 1962; 15: 473-497

Nigorikawa K, Yoshikawa K, Sasaki T, Iida E, Tsukamoto M, Murakami H, Maehama T, Hazeki K,
Hazeki O. A naphthoquinone derivative, shikonin, has insulin-like actions by inhibiting both phosphatase and tensin homolog deleted on chromosome 10 tyrosine phosphatases. Mole Pharmacol. 2006; 70: 1143-1149

Papageorgiou VP, Assimopoulou AN, Couladouros E A, Hepworth D, Nicolaou KC. The chemistry and biology of alkannin, shikonin and related naphthazarin natural products. Angewandte Chemie International Edition. 1999 38: 270-300

Schmeda-Hirschmann G, Jordan M, Gerth A, Wilken D. Secondary metabolite content in rhizomes, callus cultures and in vitro regenerated plantlets of Solidago chilensis. Z Naturforsch. 2005; 60c: 5-10

Shen CC, Syu WJ, Li SY, Lin CH, Lee GH, Sun CM. Antimicrobial activities of naphthazarin from Arnebia euchroma. J Nat Prod. 2002 65: 1857-1862

Singh B, Sharma MK, Meghwal PR, Sahu PM, Singh S. Antiflammatory activity of shikonin derivatives from Arnebia hispidissima. Phyto med. 2003; 10: 375-380

Shirin F, Sandeep K, Yogeshwar M. In vitro plantlet production system for Kaempferia galangal, a rare Indian medicinal herb. Plant Cell Tissue Organ Cult. 2000; 6: 193-197

Shivanna MB, Vasanthakumari MM, Mangala MC. Regeneration of Biophytum sensitivum (Linn) DC. Through organogenesis and somatic embryogenesis. Indian J of Biotechnol. 2009; 8: 127-131

Tabata M. The mechanism of shikonin biosynthesis in Lithospermum cell cultures. Plant Tiss Cult let. 1996; 13: $117-125$

Touno K, Harada K, Yoshimatsu K, Yazaki K, Shimomura K. Shikonin derivative formation on the stem of cultured shoots in Lithospermum erythrorhizon. Plant Cell Rep. 2000; 19: 1121-1126

Tsukada M, Tabata M. Intracellular localization and secretion of naphthoquinone pigments in cell cultures of Lithospermum erythrorhizon. Planta Med. 1984; 51: 338-341

Yazaki K, Fukui H, Tabta M. Isolation of the intermediates and related metabolites of shikonin biosynthesis from Lithospermum erythrorhizon cell cultures. Chem Pharm Bull. 1986; 34: 2290-2293

Yazaki K, Matsuoka H, Ujhara T, Sato F. Shikonin biosynthesis in Lithospermum erythrorhizon: Lightinduced negative regulation of secondary metabolism. Plant Biotechnol. 1999; 16: 335-342

Xiong W, Luo G, Zhou L, Zeng Y, Yang W. In vitro and in vivo antitumor effects of acetylshikonin isolated from Arnebia euchroma (Royle) Johnst (Ruanzicao) cell suspension cultures. Chinese Med. 2009; 4: 14-17

Received: January 15, 2016; Accepted: May11, 2016 